\title{
THE COMPARISON BETWEEN THE USE OF NHT TYPE AND STAD TYPE OF COOPERATIVE MODEL IN CONTEXTUAL APPROACH SETTING ON JUNIOR HIGH SCHOOL STUDENTS' MATHEMATICAL UNDERSTANDING
}

\author{
Ujang Cahya Setia \\ SMP NEGERI 1 CIBINONG \\ cahyasetia35@gmail.com
}

Diterima: 20 Juni 2019

\begin{abstract}
The low skill of students' mathematical understanding can affect the quality of students' learning which has an impact on the low achievement of students' in schools. One effort to improve the skill of understanding is by choosing and applying the model of learning that can enable students' eagerness to learn, namely cooperative learning model which can be used as an alternative learning model. Objectives to be gained in this study is to determine whether there is difference in the skill of mathematical understanding of junior high school students which use contextual approach setting cooperative learning model NHT type with STAD type on the subject of bangun ruang sisi datar. The method used in this research is subject experiments to students of SMP class VIII which is divided into two experimental groups, namely NHT type and STAD type. Teachers can develop cooperative learning model because it can improve students' learning outcomes. Teachers should experiment with learning methods more for the sake of the most appropriate and varied models selection.
\end{abstract}

Key words: Mathematical understanding, Cooperative Learning, NHT, STAD

\section{INTRODUCTION}

Mathematical learning in schools aims to refer to mathematical functions as well as to national education objectives that have been formulated in the Guidelines of State Policy (Garis-garis Besar Haluan Negara/GBHN), that the main purpose of providing mathematical education at the level of primary and secondary education is to prepare students to be able to deal with changes in the life of an ever-evolving world, through understanding and acting on the basis of logical, rational, critical, effective, and efficient thinking which prepares students to use mathematical thinking in their daily lives.

In science learning, to be able to achieve the expected condition, which is to improve students' learning achievement, teachers should be able to create an atmosphere that can stimulate students to be active and happy in following the learning process. Teachers must have the skill to have a learning approach with appropriate learning model 
in the learning process. This learning model should be able to enable students' eagerness to learn.

Mathematical learning will be effective when a teacher is able to develop all students' potentials, including the skill of understanding, reasoning, and learning outcome skill. Developing the creativity of studying hard habitual, honest, discipline, and having good social attitude and various skills needed in social life, is not easy for a teacher or prospective teachers in a condition where teacher is expected to develop all those potentials in teaching and learning activities. A teacher is expected to be able to implement and adapt to various teaching methods with materials or learning materials in accordance with the objectives to be achieved. Teachers should be able to select the learning methods based on students' needs, so that the students will learn with strong impetus because the learning given is considered useful.

A more serious effort from the teacher in applying the method of learning is needed in improving the students' mathematical understanding. The learning method needed is the method which is able to improve and develop students' learning ways, so that students' mathematical understanding can also be developed. One of the methods that can by used by the teacher is contextual approach or commonly called as Contextual Teaching and Learning (CTL).

As it is known that Contextual Teaching and Learning is a holistic learning process and it aims to help students understand the meaning of teaching materials by relating them to their daily life context (personal, social and cultural context). This will make the students have dynamic and flexible knowledges/skills to actively construct their own understanding and emphasize the process of their involvement in finding the material. This means that the learning process is oriented directly to the experience process. In order to discover the relationship between the material learned and the real life situation, the students are required to be able to capture the relationship between the learning experience in school and the real life.

In order to achieve such learning, the selection and development of mathematical learning in SMP (junior high school level) is emphasized on its compatibility with the condition and characteristics of the students, so that the teaching materials can be developed with orientation on the focus of the problem type to be taught. By using 
contextual learning media with the setting of cooperative model, it is expected that the learning activity will be in accordance with the needs, so that the achievement of the planned competencies can be achieved optimally.

The skill of mathematical understanding is one of the important goals in learning. This means that the materials are not only to be memorized. But more than that, it is expected that the students should be able to understand comprehensively the subject's concept. Mathematical understanding is also one of the objectives of each material delivered by the teacher. So, in order to improve the mathematical understanding, a more serious teachers' effort, such as applying certain learning methods, is required.

By using the cooperative model of contextual approach, students are expected to participate actively in the learning process, because this model emphasizes the process of searching and finding a problem faced by students in a group. Cooperative learning model (Cooperative Learning) is based on the activeness of the students' to form the concept, principal, and theory presented to them. They cultivate it actively in a group, adjusting to the knowledge scheme already possessed in their cognitive structure, and other students may add or reject it. It is expected that students who study in a group will have a better knowledge acquisition than students who learn individually.

In cooperative learning, many method types are introduced. All of these types have both advantages and disadvantages. In this regard, in order to be able to create good quality of human resources, teachers may use appropriate methods and approaches. In this case, the approach considered to be in accordance with the development of Mathematical Sciences is contextual learning approach with cooperative learning model Numbered Heads Together (NHT) and Student Teams Achievement Division (STAD) type.

By choosing and using contextual learning approach with model of cooperative learning type of Numbered Heads Together (NHT), students are divided into small groups to make a better interaction among students, and between students and teacher. Each group holds a discussion to complete the material given by the teacher. Each member is given a number that will represent his group to explain learning outcomes. Members are randomly selected by the teacher so that each group member has individual responsibility. It means that group members have to do discussion to master the material and ensure each group member knows and understands the material. Contextual approach with cooperative model 
of Student Teams Achievement Division (STAD) has advantages such as motivating students more in groups to encourage and help each other in mastering the material presented. In this model, groups are formed from high-skill, moderate, and low-skill students. Other characteristics are class presentation, group study, individual test, and awards stage. The model is expected to create an active learning environment and better communication, and also to stimulate students to give and share each other. This circumstances are not only to improve the understanding of the material, but also to improve the social interaction among students.

On the basis of these matters, the cooperative model of NHT type and STAD type through Contextual Teaching and Learning approach will be compared. So, it will be revealed whether or not there is difference in mathematical understanding skill. Clearly, this study entitled "The Comparison Between the Use of NHT and STAD Type of Cooperative Model in Contextual Approach Setting on Junior High School Students' Mathematical Understanding".

Based on the background of the study, the problem is formulated as follows: Is the skill of mathematical understanding of junior high school students whose learning using a contextual approach with the Setting of cooperative learning model type Numbered Heads Together (NHT) is better than that using Student Teams Achievement Division (STAD) type?

This study aims to determine whether there is a difference in mathematical understanding of junior high school students' between those who use NHT and STAD type of cooperative learning model in contextual approach setting.

\section{Mathematical Understanding}

The skill of mathematical understanding is one of the important goals in learning. This means that the materials are not only to be memorized. But more than that, it is expected that the students should be able to understand comprehensively the subject's concept. Understanding is the lowest level in the aspect of cognition associated with mastery or understanding of something. The term understanding is defined as the absorption of the meaning of a material being studied. Furthermore, understanding is one aspect in Bloom's Taxonomy. Understanding is also defined as the absorption of the meaning of a material matter learned. So, to understand an object in depth, one must know: 
1) the object itself; 2) its relation to other similar objects; 3) its relation to other unlike objects; 4) dual-relation with other similar objects; 5) relations with objects in other theories.

Bloom classifies understanding (Comprehension) into the second cognitive level. Understanding describes a definition, so that students are expected to be able to understand mathematical ideas if they can use their ideas to communicate. At this level, students are expected to know how to communicate and use their ideas to communicate. Understanding is not only to understand an information but also the objectivity, attitudes and meaning of an information. In other words, a student should be able to change an information in his mind into another meaningful form.

Skemp, distinguishes two types of understanding:

a. The instrumental understanding, which is to memorize something separately or to apply something to a simple/complicated calculation; does something algorithmically.

b. Relational understanding, which can link something with other things correctly and aware of the process undertaken.

Instrumental understanding is defined as the understanding of mutually exclusive concepts and only memorizing formulas in simple calculations. In this case, one only understands the order of processing or algorithms. A relational understanding contains a scheme or structure that can be used in the explanation of a wider problem and its usage properties.

Meanwhile students' understanding of mathematical concepts, according to NCTM (1989: 223), can be seen from the students' skills in: (1) Defining spoken and written concepts; (2) Identifying and creating examples and non-examples; (3) Using models, diagrams and symbols to present a concept; (4) Converting a form of representation to another; (5) Knowing various meanings and interpretations of concepts; (6) Identifying the properties of a concept and recognizing the conditions that define a concept; (7) Comparing and differenting concepts.

Contextual Teaching and Learning Approach is an effort to improve students' activeness in teaching and learning process. Gunawan, (2010: 79) states that Contextual Teaching and Learning Approach is a learning strategy that links the learning materials 
naturally with the real world of students' so it can make the connection between the knowledge they have with the life of students' as members of family and society.

Next is the Contextual Teaching and Learning approach according to Johnson (2010: 43) who states that:

the reason for the use of contextual learning because of the centralistic and uniformistic mindset that characterizes the packaging of our educational world where decisions are always carried out on the basis of hierarchies. There is a tendency in today's education to return to the idea that children will learn better if the environment is created naturally. Learning will be more meaningful if the children "experience" themselves of what has happened, not "know" it. Target-oriented learning of material mastery proves successful in short-term "remember" competencies, but fails to equip children in solving problems in long-term life. Contextual Teaching and Learning is a teaching approach whose characteristics meet the explained expectation.

From the description above, it can be concluded that the learning with contextual approach emphasizes on the use of high-level thinking, transfer of knowledge, information and data modeling from various sources.

Contextual approach as a learning approach that facilitates the learning activities of students to seek, process, and find learning experiences that are more concrete (related to real life) through the involvement of trying-to-do and experiencing-themselves learning activities. Thus, learning is not only seen from the product side, but the most important is the process. Therefore, the teacher's job is to plan and use the appropriate learning strategy of how this strategy is considered more effective in guiding the students' learning activities in order to find what they hope.

\section{Advantages and Disadvantages of Cooperative Learning Model}

Each learning model has advantages and disadvantages, as well as Cooperative Learning. According to Slavin (1997: 21), Cooperative learning has advantages and disadvantages as follows:

a. It can develop students' achievement, both test results made by teacher as well as standard test.

b. Students' confidences are on the rise, students feel more controlled for their academic success. 
c. Cooperative strategies provide impressive developments in interpersonal relationships among members of different ethnic groups.

Cooperative learning model STAD method has not been widely applied to our education world. Most teachers are reluctant to apply this system for several reasons. Lie (2002: 22) states that the reason teachers are reluctant to apply cooperative learning in class ie:

a. Concerns that there will be chaos in the classroom and students do not wish to learn if they are placed in groups.

b. Many people have negative impressions of cooperative activities or learning in groups.

c. Many students are not happy to be told to cooperate with others.

d. Diligent students may feel that they have to work more than other students in their group, while the less able students may feel inferior to be placed in a group with smarter students.

e. The diligent students may also feel that their underprivileged teams just ride on their toil.

According to Slavin (1995: 21), Cooperative learning has the following disadvantages:

a. If the teacher fails to remind the student to always use the cooperative skills in the group, the group dynamics will appear to be stuck.

b. If the number of groups is not considered, for example less than three, then a member will tend to withdraw and less active in the discussion. Conversely, if the group is more than five, then there is a possibility that some members will only just put their names because no tasks for them. If the group leader can not constructively resolve the conflicts, then the group work will be less effective.

\section{The Research Method}

In collecting data needed to achieve the objective, experimental method is used, because there are manipulations of treatment. This research consists of two variables that are independent variable and dependent variable. The independent variable is the skill of mathematical understanding of students whose learning uses a contextual approach with 
the Setting of Cooperative Learning Model of NHT type and STAD type cooperative learning model.

The experimental design used in this study is the pretest-postest control group design (Ruseffendi, H.E.T. (2010:50). The population in this research is all students of class VIII SMPN 1 Cibinong Cianjur District in the academic year of 2012 -2013. The sample in this research is taken 2 class randomly that is class VIII A as experiment class (experiment I), and class VIII E as control class (experiment II).

\section{The Result}

Based on the processing and analysis of the pretest and postest data, the result is presented in the following table:

Table 1. Normality Class Data Test of the Use of NHT Learning Type

\begin{tabular}{llllllc}
\hline \multicolumn{2}{c}{ Class Test } & Mean & StDev & N & AD & P \\
\hline $\begin{array}{l}\text { NHT } \\
\text { Type }\end{array}$ & Pretest & 29,29 & 15,35 & 35 & 0,427 & 0,296 \\
\cline { 2 - 7 } & Postest & 74,43 & 10,13 & 35 & 0,445 & 0,278
\end{tabular}

From the data above, the pretest for Mathematical understanding class, which uses NHT type learning model, has P-Value $>0,440$. This means that Ho is accepted and normally distributed. For postest, this class has P-Value $>0.278$ which is concluded that Ho is accepted and the NHT type is also normally distributed.

Table 2. Normality Class Data Test of the Use of STAD Learning Type

\begin{tabular}{ccccccc}
\hline \multicolumn{2}{c}{ Class Test } & Mean & StDev & N & AD & P \\
\hline $\begin{array}{c}\text { STAD } \\
\text { Type }\end{array}$ & Pretest & 30,74 & 13,82 & 34 & 0,289 & 0,594 \\
& & & & & & \\
\cline { 2 - 7 } & Postest & 70,14 & 10,11 & 35 & 0,470 & 0,233
\end{tabular}


From the data above, the postest for mathematical understanding class, which uses NHT type learning model, has P-Value $>0,278$. This means that Ho is accepted and normally distributed. For mathematical understanding class which uses STAD type learning model, the P-Value $>0.278$ which is concluded that Ho is accepted and the NHT type is also normally disrtibuted.

Based on the data analysis on the comparison of junior high school students' mathematical understanding skill who have been treated using Numbered Heads Together (NHT) and Teams Achievement Division (STAD) type of contextual teaching approach's cooperative learning model, it is found that there is an improvement in students' mathematical understanding skill.

Prior to the implementation of the study, the pretest is conducted with the aim of knowing whether there is a difference between the two classes used as research objects. The test results show no difference which means that the students have not been treated in both experiment classes. The final result shows that there is also no difference. In this case both models have no advantages in improving students' mathematical understanding. The factors that cause the skills of students' are not different significantly can be seen as follows:

1. The skills of students' mathematical understanding before being given treatment have similiarity, even though the students are in different class, that is students can understand the same subject matter.

2. Although the two types of learning used are different, but in the implementation of learning, students have high activity so the results obtained are not significantly different.

3. Before the implementation of learning, the students, both using NHT or STAD learning type, do not experience any difficulties. 


\section{BIBLIOGRAPHY}

Arikunto, Suharsimi (2006). Prosedur Penelitian. Jakarta: Rineka Cipta.

Arikunto, Suharsimi (2002). Dasar-dasar Evaluasi Pendidikan. Jakarta: Bumi Aksara.

Arikunto, Suharsimi (2009). Dasar-dasar Evaluasi Pendidikan. Jakarta: Bumi Aksara.

Alsailah, C.A. (2005). Contextual Teaching and Learning Menjadi Kegiatan Belajar Mengajar Mengasyikan dan Bermakna.Bandung: MMC

Gunawan, A. W. (2010). Genius Learning Strategy. Jakarta: PT Gramedia Pustaka Utama. Ibrahim, R. dan Sudjana, N. (2003). Perencanaan Pengajaran. Jakarta: Rineka Cipta.

Johonson, Elanie B. (2010). Contextual Teaching \& Learning, Terjemahan Alwasilah A. Chaedar. Cetakan ke 1. Bandung: Kaifa.

Lie, Anita (2002). Cooperative Learning. Mempraktikkan Cooperative Learning di RuangRuang Kelas. Jakarta: Gramedia.

NCTM. (1989). Curuculum and Evaluation Standards for School Mathematics. Reston, VA: NCTM.

Ruseffendi, H.E.T. (2010). Dasar-dasar Penelitian Pendidikan dan Bidang non-Eksakta lainnya. Bandung: Tarsito.

Slavin, Robert, E. (1995). Cooperative Learning: Theory, Research and Practice. Scond Edition. Boston: Allyn and Bacon Publisher.

Slavin, Robert (2008). Cooperative Learning Teori, Riset dan Praktik. Bandung : Nusa Media

Surakhmad, W. (1994). Penghantar Penelitian Ilmiah. Bandung: Tarsito. 